\title{
OBSERVATIONS ON THE HISTOGENESIS OF PRO- TOPLASMIC PROCESSES AND OF COLLATERALS, TERMINATING IN END BULBS, OF THE NEURONES OF PERIPHERAL SENSORY GANGLIA
}

\author{
G. CARL HUBER AND STACY R. GUILD
}

Department of Histology and Embryology, University of Michigan

FIFTY-FOUR FIGURES

In a study of the spinal ganglia of vertebrates, stained after the Ehrlich intravitam methylene blue method, Huber observed, especially in the spinal ganglia of amphibia, fine collateral branches arising from the intracapsular portion of the nerve process, having a recurrent course and ending beneath the capsule or on the cell body of the respective cell in relatively large discs or end bulbs. Similar structures, though not so successfully stained, were observed in the spinal ganglia of certain turtles and the rabbit. In the publication cited reference was had mainly to the presence of these structures as observed in the frog, incidental mention is made of their presence in the turtle spinal ganglia and no mention was made of their having been observed in mammalia, owing to the fact that that staining of these structures in the mammalian spinal ganglion was not wholly successful and the question of possible artefacts was given undue consideration. Little attention was paid to these structures until they were practically rediscovered by Cajal whose observations were made on the spinal ganglia of man and certain of the larger mammals stained after his silver impregnation method. Cajal designates these cells as "Regenerativer Typus oder Typus mit Fortsätzen, welche in verkapselten Kugeln endigen," and describes three main forms: (a) elements whose processes end in endocapsular bulbs. This is the most common variety and is found on cells of the glomerular type. The side processes are said to arise either from the 
cell body, from the axon cone or from one of the turns of the glomerulus. They have a diameter of from $0.3 \mu$ to $0.4 \mu$ enlarging as the end disc is approached and terminating in variously formed end discs, or bulbs; (b) Elements, with processes which pierce the capsule, and terminate in end discs situated in the interspaces of the ganglion. These are quite numerous in man and are quite variable. The processes are relatively fine and may arise from the cell body or from the endocapsular portion of the nerve process or again from its extracapsular portion and end at a variable distance from the cell. The end discs may terminate at some distance from the cell body, even in the nerve trunk outside of the ganglion; (c) Mixed forms, with transitions between endocapsular and extracapsular dises and elements having both types of dises. Dogiel in his excellent monograph on the structure of the spinal ganglia classifies neurones with processes terminating in end bulbs under Type II. This type is characterized as composed of cells from the main process of which arise side branches - collaterals - which terminate in platelets varying in form and size. He recognizes three subtypes: $(a)$ cells from the main process of which there arise, usually near its origin from the cell, relatively short processes which may have a wavy or coiled course and end endocapsular in relatively large end discs; $(b)$ cells from the main process of which there arise, at a variable distance from the cell, fine and relatively long collaterals which wind about in the capsule of the respective cell and terminate in variously formed plates; $(c)$ cells from the extracapsular portion of the nerve process of which there arises usually a single fine collateral which may be relatively long, spirally wound about the nerve process and ends in the interstitial tissue in a relatively large end disc. Dogiel does not recognize fine processes arising from the cell body of the spinal ganglion cells and ending in end dises. Von Lenhossék has described and figured fine processes arising from the cell body and a turn of the glomerulus in spinal ganglion cells of the horse. Chase has also described processes terminating in end bulbs, the process being connected either with the cell body or with the axon Ranson's Type II, spinal ganglion cells are characterized as "Cells whose axons have 
collaterals ending in end bulbs." Three subgroups are considered: $(a)$ cells having collaterals ending in end bulbs which arise before the axon leaves the capsule of the respective cell; $(b)$ cells having collaterals which arise from the axon at some distance from its cell origin and pierce the capsule of some other cell, terminating in an end bulb which lies on the surface of this second cell; (c) collateral which run in the connective tissue of the ganglion and end in end bulbs surrounded by a special capsule. Ranson did not observe fine branches ending in end discs which arise from the cell body of the spinal ganglion cells, thus of the nature of dendritic branches. Levi has studied the spinal ganglia of fishes, reptiles and mammals by means of the silver impregnation method and has found the fine processes ending in end bulbs in the various forms examined. They are described as especially numerous in the cranial ganglia of primates, where the atypical forms of ganglion cells are said to constitute the prevalent type. He has considered also the histogenesis of these structures and this portion of his work will receive further consideration.

Fine processes arising from the cell bodies of spinal ganglion cells and as collaterals from their axons, and ending in relatively large end bulbs have received especial attention by neurologists and neuropathologists since it has been shown that they are present in much greater numbers in certain pathological conditions. Nageotte and later Marinesco and others have shown that they were quite numerous in the spinal ganglia of subjects afflicted with tabes, also numerous in transplanted spinal ganglia, or partly crushed ganglia or again ligated ganglia. Nageotte has regarded these structures as an exponent of a special type of regeneration to which he has given the name of 'collateralregeneration' in contradistinction to the regeneration observed at the end of a severed nerve. This hypothesis has been accepted by Marinesco and Bielschowsky. The latter has studied both the normal and pathological ganglia of man, using his well known silver method and gives numerous figures showing form and relation of these structures. He regards them as an evidence of an attempted regeneration and as found only on cell bodies and processes of neurones showing evidence of degeneration. His own words read 
as follows: "Die Regeneration ist niemals eine autochthone. An gesunden Neuronen zeigt sie sich nie. Sie erscheint stets als Folge einer primären Destruktion. Wo Sprossungsvorgänge an Zellen und Fasern stattfinden, können wir mit Hilfe unserer verschiedenen Methoden den Nachweis führen dass dieselben in ihrer Struktur mehr oder minder verändert sind." Cajal regards the hypothesis of Nageotte as giving the correct interpretation of the meaning of the cell process and collaterals ending in discs. His own words read as follows. "Wir sehen demnach gegenwärtig die kugeligen Verbreitungen als regenerierte oder neugebildete Nervenfasern und folglich als das Resultat eines transitorischen Bildungsvorganges an, der in allen Typen der sensiblen und sympatischen Zellen und selbst in den Nervenfasern der cerebrospinalen Centren vorkommen kann." Cajal does not regard the neurones showing these processes as necessarily pathologic. The regeneration is usually purposeless. Cajal compares these end discs to the end bulbs of regenerating nerve fibers. The 'Kugelphänomen,' to use his word, is regarded as an interesting process which has recently been well analyzed by Nageotte who should be credited with throwing light on an important biologic phenomenon. Rossi, who has extensively studied normal and pathologic spinal ganglia of man, groups the cells with processes ending in bulbs as follows: (a) Cells with processes the end bulbs or 'bolas' of which are endocapsular; (b) Cells with processes the end bulbs or 'bolas' of which are extracapsular and at times relatively far distant from the cell of origin; (c) mixed or transitional types. He discusses fully Nageotte's hypothesis of 'collateralregeneration' and reaches the conclusion that this is not substantiated. The large number of such structures found in pathological conditions, especially tabes, is not regarded as evidencing a regenerative process since the increase may be apparent rather than real, in that the pathological tissues may be much more receptive to silver impregnation than the normal tissues. He states, to use his own words, "Es wäre ja leicht möglich, und eine solche annahme ist weder unwahrscheinlich noch unlogisch, dass, wenn die Mehrzahl der Ganglienzellen sich im Zustande grosser Veränderung befinden, die fraglichen Fasern in Verhältnissen sein könnten, 
welche die Imprägnierungen mit dem Silbersalz begünstigen, und sie für die nachfolgende Einwirkung der Reduzenten mehr aussetzten." Rossi further lays stress on Levi's observations on the histogenesis of these structures and points out that the fact that these structures are present in relatively early stages of embryonic development would seem to indicate that they are normal structures and not expressions of regenerative phenomena. The hypothesis that the processes and collaterals of spinal ganglion cells, ending in end bulbs, are the products of regenerative activity of the neurones has led.Ranson to see whether they are increased in number in ganglia after the division of the associated nerves. The left sciatic was cut in four dogs and after one month the associated ganglia were prepared by the pyridin-silver technic. The results of these experiments were entirely negative.

It is not at all difficult to find in the spinal ganglia of adult mammals, neurones presenting the various types of cell processes and collaterals ending in end bulbs, as described by authors, both for normal and pathological tissues. In a series of preparations of spinal ganglia of adult rabbits, cats and dogs, stained after the pyridin-silver technic of Ranson, modified by fixing the tissues by means of a preliminary injection of ammoniated alcohol, as described by Huber and Guild, such structures are readily found. It is not our purpose, however, to consider these structures as observed in adult ganglia, except to add that the neurones on which they are found do not present evidence of degenerative changes, and that the nonmedullated fibers of the ganglia are not thus accounted for, even to a minor degree, as might be supposed from the statements of Bielschowsky. Attention may be called to the fact that Ranson has clearly traced the nonmedullated fibers of the spinal ganglia to origin from small cells of these ganglia. It occurred to us that a study of the histogenesis of these structures might offer interesting data and our study was undertaken with this end in view. At the time when these observations were projected we were not aware of Levi's studies in this field. Our own observations, in part confirmatory, extend those of this observer and seem to us worthy of record, especially in view of the fact that an especial interest is attached to these structures by 
the neuropathologist. Our study is based in the main on material taken from rabbit embryos and young rabbits. Further on threeday-old rats and puppies about three weeks old. The study is confined largely to the lower cervical ganglia and the upper dorsal ganglia, mainly owing to the somewhat better staining obtained here than in the cranial ganglia, which material was used for other purposes, for which it was not permissible to cut the heads in smaller pieces. Where possible, by reason of size and convenience, the embryos and young animals used were subjected to a preliminary injection of the ammoniated alcohol before final fixation of the tissue. This is of advantage and adds to the method. The elements are better fixed and are slightly separated so that thicker sections may be studied to advantage. We also found it very convenient to combine decalcification with the silver technic. After the injection of ammoniated alcohol, or without this, the cervical and upper dorsal spinal column was removed with the surrounding muscular tissue, cut in segments having a length of about $1 \mathrm{~cm}$., fixed in ammoniated alcohol, decalcified, subjected to silver impregnation and reduction, embedded in paraffin and cut serially. In the region selected the ganglia are relatively large and are arranged more nearly at right angles to the long axis of the cord than in other regions. In the sections the ganglia are oriented with reference to the cord and associated nerves, and are in no way affected by manipulation. The figures, as may be observed from the legends, are all taken from rabbit material, and mainly from the spinal ganglia of rabbits one day old, in which the series of developmental stages was most readily found. Similar stages are also found in the three-day-old rat material, so that it would be a simple matter to duplicate the figures here given from rat material. In spinal ganglia from six-day-old rabbits, cell processes and collaterals ending in bulbs are easily found, though what we have regarded as the early developmental stages are not numerous. In the spinal ganglia from 3-cm.-rabbit embryos, the cells are mostly of the type of bipolar cells, many showing early stages of single process formation. In the spinal ganglia of rabbits removed about one week before birth there are to be found series of stages showing spinal ganglion cell development, 
beginning with the late bipolar stage to cells with relatively well developed single processes with T- or Y-shaped division. Only here and there a few cells showing lobulation or early stages in the formation of the processes ending in end bulbs are seen. Certain of the most typical of these are figured. The spinal ganglia taken from puppies three weeks old show neurones with processes and collaterals ending in end bulbs, but these are not as numerous as in the rabbit material and show a somewhat later stage of development than the oldest stages figured by us. The material taken from the rabbits one day old, from which material most of our figures were made, had been well injected with ammoniated alcohol, prior to removal from the animals and final fixation in the ammoniated alcohol. The neurones in the ganglia seemed well preserved, both as to form and structure, many of the cells and processes showing neurofibrils. The structures figured, we believe, are not artefacts, due to possible shrinkage and consequent distortions of the cells.

The cell processes and collaterals terminating in end bulbs, may, according to their histogenesis, be grouped under three heads, though not very much weight is attached to such a classification, in that it is not always possible to project with certainty the future relations of these structures when seen only in anlage. The grouping is as follows.

1. It seems quite evident that a certain group of processes or collaterals arise as protoplasmic buds from the processes of the unipolar cells, the primary axons, and at a variable distance on this from the cells of origin. The majority of these collaterals appear to end ultimately on the cell body of some other neurone, certain ones perhaps in the interstitial tissue, though the possibility of certain ones having a recurrent course and ending on the cell of origin is not excluded.

2. Processes which arise as protoplasmic buds from some portion of the cell body. The point of origin may be near the axon cone or at a variable distance from it. In further development such buds do not become associated with the axon cone but remain as protoplasmic branches, perhaps of the value of dendrites. Later developmental stages indicate that certain of these branches 
remain as endocapsular processes, while others pierce the capsule to end on some other cell or in the interstitial tissue.

3. Processes which arise from the cell body near or at the root of the axon cone which, as the axon cone and processes undergo further development become drawn on to the axon and thus become distinctly separated from the cell body. These processes or collaterals, it would appear, may end on the cell body of the cell of origin or perhaps also on the cell body of some other cell or in the interstitial tissue.

In the main, our figures are grouped with reference to such a classification. The figures are all drawn with the aid of a camera lucida, at a magnification of 1000 , in the reproduction reduced to 500. It was found very helpful to use during the study of the preparations and while making the outline drawings with the aid of the camera lucida, a strong Welsbach light; many of the details being much more clearly visible than when daylight alone is used. In our selection of cells for drawings such cells as gave the full detail in one section were chosen. None of the figures represent graphic reconstructions. We believe that they portray the facts to be presented so clearly that we may be correspondingly brief with our morphologic description.

Figures 1 to 17 all show collateral branches developing from the nerve processes or primary axons and at variable distances from the cells which give them origin. All of the figures except 17 (6-day-old rabbit) are from spinal ganglia of rabbits one day old. Figures 1, 2 and 3 show the anlage of these collateral branches. In figure 1 is shown a short bud arising from the neuraxis a short distance from its origin. Such buds recognized here and there on fibers, stain a lighter brown than does the parent fiber and show a much looser arrangement of the neurofibrillar network than does the fiber. In figure 2 a similar bud, somewhat more distant from the point of origin of the process is seen as resting on the fiber; its relative size is thus clearly shown. In figure 3 is shown the anlage of a collateral given off from a primary axon just before its T-shaped division is reached. The length of this process could not be determined. Figures 4,5 and 6 show early stages in the basal constriction of the bud like anlagen of collaterals and it may 
be seen that the bulbus ends stain usually a light brown, the stalks staining a somewhat darker brown. To bring out the perspective in the drawings, it was not always possible to retain the relative degree of coloration as presented in the preparations and therefore, certain of the buds and bulbus ends are figured as more deeply stained than is the case in the sections. Figures 7, 8, 9, 10 and 12 show progressive stages in the degree of constriction and elongation of the stalks of the respective collaterals ending in bulbs. In figure 7 may be seen a relatively large end bulb of somewhat irregular shape, resting on a cell other than that from which arises the process bearing the collateral branch. These collateral branches with the exception perhaps of that shown on the cell and process presented in figure 9, are extracapsular in origin. In this figure (9) the nerve process, as may be seen by altering the focus, is longer than the figure would lead one to suppose and is inserted at a deeper portion of the cell than is figured. Figure 14 shows a collateral branch with a large stalk and a bulbus end, also large, which appeared to rest on another cell. Figures 13, 15 and 11 show well formed collateral branches of about the thickness as found in adult ganglia, though as yet relatively short, ending in well formed end bulbs. The collateral branches enlarge slightly as the bulbs are reached, this section staining somewhat more deeply, this is as is described by Cajal. These three cells show clearly the variable distance from the cell body giving origin to the respective process, at which the collateral branches may arise. In figure 11 the end of the fiber as figured, is in the immediate vicinity of T- or Y-shaped branchings of other processes, the collateral branch appears therefore, to be given off near the branching of the respective fiber and may represent a later developmental stage of that shown in figure 3 . In figure 16 there is shown a relatively large collateral branch, nearly as large as the parent fiber with extracapsular origin, sweeping over the parent cell and ending in a large disc surrounded by a distinct capsule, not figured. This shows a relatively late stage in development and is not unlike similar structures found in adult ganglia. This cell is situated immediately under the ganglionic capsule as is also the end disc. Figure 17, from the spinal ganglion 
of a six-day-old rabbit, shows clearly a collateral branch with relatively large end disc, arising from the process of one cell and ending on another cell, the latter cell showing the light halo which surrounds an end disc apparently resting on the cell body, and familiar to one of us from former work with the intravitam methylene blue method. A second fibril with cut end, arising from the collateral branch near its end bulb, is evident. This probably represents a second disc cut in sectioning. The collateral branch shows an enlargement at about its middle, which from structure and staining suggests the anlage of another end dise.

Figures 18 to 29 are given to show the development of processes ending in bulbus ends and arising directly from the cell bodies of ganglion cells. Such processes are denied by certain observers (Dogiel, Ranson) but are seen clearly as a distinct type in development. They develop as outgrowths from the cell protoplasm, lobulations of the same as stated by Levi and are not related in development to fenestration of cell protoplasm leading to festoon formation or protoplasmic loops or peripheral protoplasmic reticular formation as described for certain types of spinal ganglion cells, by a number of observers. Bielschowsky regards the protoplasmic branches of spinal ganglion cells as developed from protoplasmic loops, these breaking through at their highest point. He states, "Ich halte diese Gebilde für Henkelfragmente, die auf der Höhe des Bogens abgeschnürt worden sind." In our preparations there is at the stage of development here studied, and especially in the spinal ganglia, very little evidence of fenestration of the cell bodies of the ganglion cells. In figure 25 we present a spinal ganglion cell, including its process to and inclusive of the T-shaped division, in which there is shown a distinct outgrowth to one side of the cell body, slightly constricted at its base. This we regard as the anlage of a process ending in a bulbus end disc. The outline of the surrounding cells is so regular that the appearance presented by this cell is not regarded as due to distortion consequent to shrinkage. Our method of fixation by preliminary injection of ammoniated alcohol, we believe excludes this. Here and there cells presenting the same general appearance are to be observed. Figures 18 and 19 show slightly older stages of develop- 
ment, with constriction at the base of the outgrowth. Each eell shows only one outgrowth. This in itself precludes the fragmentation of a loop. The very large end bulb evident from the time of the anlage of the process argues against the assumption that these processes are developed by fragmentation of the protoplasmic loops. In figures 21,22 and 23 are shown progressive stages in the constriction and elongation of the protoplasmic branches terminating in end bulbs. In figure 23 there is evidence of a second bud growing from the process figured and in figure 22 there is shown a process which after division ends in two bulbs, possibly a later stage of development of the condition shown in figure 23 . Figures 24 and 26 show cells with their processes ending in large end bulbs, not unlike similar structures as observed in adult ganglia. Figure 24 presents further a cut collateral branch, arising from the process of the cell some distance from its origin, the end disc no doubt having been severed in sectioning the preparation. In figures 27,28 and 29 are shown small protoplasmic processes ending in relatively small dises, varying in shape and having an endocapsular position and not unlike similar structures met with in adult ganglia. The figures presented appear to us to indicate a progressive development of protoplasmic branches ending in bulbus ends as observed in spinal ganglia. Certain of our figures are not unlike those presented by Marinesco and Minea (Neuro Biologica) showing the results of partial crushing of spinal ganglia. Their figures 4, 9,10 and 11 appear to show what may be regarded as early stages of development of processes with end discs of spinal ganglion cells. Figures 24, 26 and 28 are from spinal ganglia of rabbits six days old, the other figures of this series are from the spinal ganglia of rabbits one day old.

The cells shown in figures 30 to 36 may be regarded as representing a subgroup of type 3 of our classification, in which the processes with end bulbs arise from the cell bodies of the ganglion at the base of the axon cones, which in further development are drawn on to the primary axons appearing to arise from them near their seat of origin. All of these figures except figure 31, which is from a spinal ganglion of an embryo rabbit one week before birth, are from spinal ganglia of rabbits one day old. Figures 31 and 32 
represent cells which show early stages in the development of such processes, presenting each a relatively large lobule of protoplasm attached to the base of the axon cone by means of a short thick stalk. In figures 33 and 34 are shown cells in which the lobules of protoplasm, which are to form the end bulbs of the respective processes or collateral branches are attached to the primary axons slightly further from their place of origin than is the case in the preceding figures, as yet, however by short thick stalks. In the cells shown in these four figures (31 to 34 ) it seems quite clear to us that the bud developed either as an outgrowth from the cell body at the base of the axon cone or from the base of the axon cone itself and was drawn along the primary axon as it developed. In the cells shown in figures 36 and 37 , the process for each cell, which may now be regarded as a collateral branch, is thinner and longer and ends in a relatively large end bulb. Here also it seems probable that these processes had their origin at the base of the axon cone and were separated from the cell body during later development. For the cells shown in figures 30 and 35 this mode of development can only be conjectured; we cannot exclude the possibility that in these cells the processes in question did not arise as collateral branches from the respective axons in about their present relative position. However, after a study of many similar examples it seems to us clear that there are to be found on the cells of the spinal ganglia, certain collateral branches which arise from the base of the axon cones, which in anlage are to be regarded as buds from the cell body of the respective cells and which are drawn on to the primary axons as these and the processes undergo further development.

In figures 38 to 45 , is shown a group of cells which form a second sub group under division three of our classification. Of this series of figures all but figure 38, which is from the spinal ganglion of a rabbit embryo one week before birth, are from the spinal ganglia of rabbits one day old. In all of these cells the anlage of the process or collateral branch ending in a bulbus enlargement arose from the cell body of the respective cell at the base of the axon cone and retains this relation in further development. It is a question as to whether these processes are to be regarded as processes of the 
cell bodies of the ganglion cells or as collateral branches of their primary axons. Certain ones appear to remain endocapsular, others appear to pierce the capsule ending in dises which are extracapsular in position. Their relation to the glomerulus when this develops, could not be determined at this stage of development. In figure 38 is shown a cell taken from the spinal ganglion of a rabbit embryo removed about one week before birth, which shows the anlage of the processes of this type, as a bud from the region of the junction of the axon and cell body. Even at this early stage in development the bud like anlage shows a bulbus end with relatively short thick stalk. This figure resembles certain of the figures given by Levi (figures 11 to 13) taken from the spinal ganglia of 12-cm.-long Sus scrofa embryos. In figure 39 is presented a cell showing an early stage in the development of this type of process, with bulbus end and short thick stalk arising from the base of the axon cone. Figures 40 and 41 present cells showing older stages with longer and thinner stalks ending in conspicuous end bulbs. Figure 42 is inserted since it shows a cell presenting an end view of the axon cone and process of a stage similar to that shown in the two preceding figures and shows clearly the attachment of the process at the end of the axon cone. Figures 43, 44 and 45 present cells showing later developmental stages with relatively thin porcesses ending in conspicuous end bulbs much as are often seen in adult tissue. In figure 44 a second similar process, though less fully developed, may be seen and in figure 43 the enlargement found about the middle of the process figured seems to indicate the anlage of a second end bulb It is believed that this series of cells shows clearly the anlage and development of cell processes or collateral branches arising from cells near the bases of the axon cones and retaining this relative position in later developmental stages and probably in the adult cells.

In figures 46 to 54 we present a series of cells each showing more than one process, differing in mode of origin, or showing other special features. They are all taken from spinal ganglia of rabbits one day old. In figure 46 is shown a segment of a primary axon showing an early stage in the development of two collateral branches arising from a common stalk. The nerve cell of which 
this fiber is a part could not be determined in the section. The condition presented is unusual in that usually only a single collateral branch ending in an end bulb is observed in the course of the fiber some distance from its cell of origin. The collaterals and end bulbs in themselves show no special features. In figure 47 is shown a cell with protoplasmic processes arising directly from the cell body, as in type two, and a collateral branch arising from the primary axon, as in type one. Essentially the same appearances are presented by the cell shown in figure 48 , with the exception that one of the processes arises from the base of the axon cone as in the second subgroup of Type 3 . In figure 49 is shown a cell presenting a well developed protoplasmic process ending in a conspicuous bulb, to the left of the figure and a similar process in anlage to the right of the figure, further, a collateral branch arising from the primary axon at some distance from its origin from the cell body. These three processes on the same cell, present different stages of development. The cell shown in figure 50 presents an appearance not often met with. From the primary axon there arise three collateral branches, shown in early stages of development. The one most distally placed shows a lobulation indicating the formation of two end bulbs with collateral branches. One may conjecture that such a cell may develop into one "having two, three or more end bulbs which lie close together in a feltwork of fine fibers, the whole surrounded by a capsule" as described by Ranson. In figures 51,52 and 53 are presented cells which show early stages in the development of two collateral branches from each of the respective primary axons, situated at different distances along the axon and showing progressive stages in development. They are in every respect like collateral branches shown in figures 1 to 17 , except that here two collateral branches are seen in process of development on each primary axon, a condition now and then met with in adult spinal ganglia; although fully developed tissues are not so favorable for having both collaterals in the same plane so that they may appear in the same section. In figure 54 is shown a cell which presents an early stage in fenestration of the cell protoplasm at the base of the axon cone, at the same time showing a short collateral branch with end bulb. 
Fenestration of the cell bodies of ganglion cells we have not often met with in the spinal ganglia of the stages studied. The cell presented may readily be interpreted as showing an early stage of development of a type of ganglion cell now well known from descriptions and perhaps more easily found, at least in the animals studied by us; rabbit, dog and cat, in the vagus ganglia. A cell type in which the axon arises by means of several branches which may further branch and anastomose and form complex loops from which collaterals with end dises may arise.

From a study of the material at our disposal we believe that we are warranted in concluding that the cell processes and collateral branches of spinal ganglion cells terminating in end bulbs are to be regarded as normal and necessary components of the peripheral sensory neurones. The fact that they show a regular course in development and metamorphosis and are developed at an early period in the functional activity of the peripheral sensory neurone seems to us to offer valid support for this view In the rabbit, as has been seen, they make their appearance late in embryonic life and their production or development is especially active soon after birth. In our material from three-day-old rats, cell processes and collateral branches of spinal ganglion cells ending in end bulbs may readily be seen and the developmental stages as given for the rabbit ascertained. In the spinal ganglia of puppies about three weeks old, cell processes and collateral branches with end bulbs are found well developed and it is difficult to find the earlier developmental stages. Except for length of the collateral branches and cell processes ending in end bulbs, and a complexity in their course, those found in the spinal ganglia of newly born animals present essentially the same structure as those found in the spinal ganglia of adult animals, and would appear to be quite as numerous. In the newly born animals examined, the primary axons do not present the coil complex or glomerulus found in adult ganglia. The structure as a whole, as regards fenestration of protoplasm, division of primary axons in course or at axon cones, and so forth, is much simpler than in adult ganglia. It is difficult for us to conceive how such structures-cell processes and collateral branches ending in end bulbs--could be the exponents of 
regenerative activity, such activity affecting the peripheral sensory neurones late in embryonic life and soon after birth, the results of such regenerative activity-cell processes and collaterals with end bulbs - to remain inactive and nonfunctional and show no essential growth as age advances. It is at present difficult to ascribe a special function to such structures. We believe, however, that such function exists. It is not thought that they have simply a trophic function, subserving the nutrition of the neurone. It is quite possible that they may convey impulses. The fact that a cell process or collateral branch ending in an end bulb and arising from one cell may terminate on another cell, suggests this. They may serve to increase the surface of the cell giving larger, perhaps special fields of contact for the termination of other neurones. For the present, however, no definite statement as to the possible function of cell processes and collateral branches ending in end bulbs as found on the peripheral sensory neurones can be made. They deserve further study both from the experimental side and in pathologic conditions. 


\section{BIBLIOGRAPHY}

Bielschowsky, M. 1908 Über den Bau der Spinalganglien unter normalen und pathologischen Verhältnissen. Jour. f. Psych. und Neurol., vol. 11.

CAJAL, S. R. 1907a Die Struktur der sensiblen Ganglien des Menschen und der Tiere. Ergebnisse der Anatomie und Entwickelungsgeschichte. Bd. 16.

1907b Die histogenetische Beweise der Neuronentheorie von His und Forel. Ant. Anz. Bd. 30.

Chase, M. R. 1909 A histological study of sensory ganglia. Anat. Rec., vol. 3.

Dogrex, A. S. 1908 Bau der Spinalganglien des Menschen und der Säugetiere. Fischer, Jena.

Huber, G. CArL 1896 The spinal ganglia of Amphibia. Anat. Anz., Bd. 12.

HUBER, G. CARL, AND GUILD, S. R. 1913 Observations on the peripheral distribution of the nervus terminalis in mammalia. Anat. Rec., vol. 7.

v. Lenhosś́k, M. 1907 Zur Kentniss der Spinalganglienzellen. Arch. f. Mik. Anat., Bd. 69.

Levi, G. 1907 Struttura et istogenesi dei ganglii cerebrospinali nei Mammiferi. Anat. Anz., Bd. 30.

Marinesco, G. 1908 Recherches expérimentales et anatomo-pathologiques sur les cellules des ganglions spinaux et sympathiques. Jour. f. Psych. und Neurol., Bd. 13.

Marinesco, G., and Minea, J. 1908 Recherches expcrimentales et anatomopathologiques sur les lésions consécutives à la compression et à l'écrasement des ganglions sensitifs. Neuro Biologica, vol. 1.

NAGEOTte, J. 1906 Régéneration collatérale de fibres nerveuses terminées par des massues de croissance, a l'état normal; lesions tabetique des racines medullaires. Nouvelle Iconographie de la Salpetrière, No. 3 (seen only in review).

RANSON, S. W. 1912 The strucure of the spinal ganglia and of the spinal nerves. Jour. Comp. Neur., vol. 22.

Rossi, G. 1908 Utber einige morphologische Besonderheiten der Spinal ganglien bei den Säugetieren. Bemerkungen über die sogennannten Collateralregeneration. Jour. f. Psych und Neurol., Bd. 11. 
All of the figures are taken from spinal ganglia of rabbit embryos and very young rabbits, stained after the pyridin-silver method, combined with decalcification. The great majority of the figures are taken from tissue injected with ammoniated alcohol, prior to final fixation and hardening in the same. All of the figures were drawn with the aid of the camera lucida at a magnification of 1000 diameters, reduced in the reproduction to a magnification of 500 diameters.

\section{PLATE 1}

EXPLANATION OF FIGURES 1 TO 17

This series of figures is given to show the anlage and histogenesis of collateral branches terminating in end bulbs and arising from the primary axons of spinal ganglion cells. Figures 1 to 16 are from spinal ganglia of rabbits one day old; figure 17 , from the spinal ganglion of a six-day rabbit.

Figs. 1 to 6 Show the anlage as lateral buds and the basal constriction of such buds, of collateral branches with end bulbs arising from the primary axons of spinal ganglion cells.

Figs. 7 to 17 Show progressive stages in the metamorphosis of collateral branches ending in end bulbs which arise from the primary axons of spinal ganglion cells; also show the relative position on the primary axon of such collateral branches. 

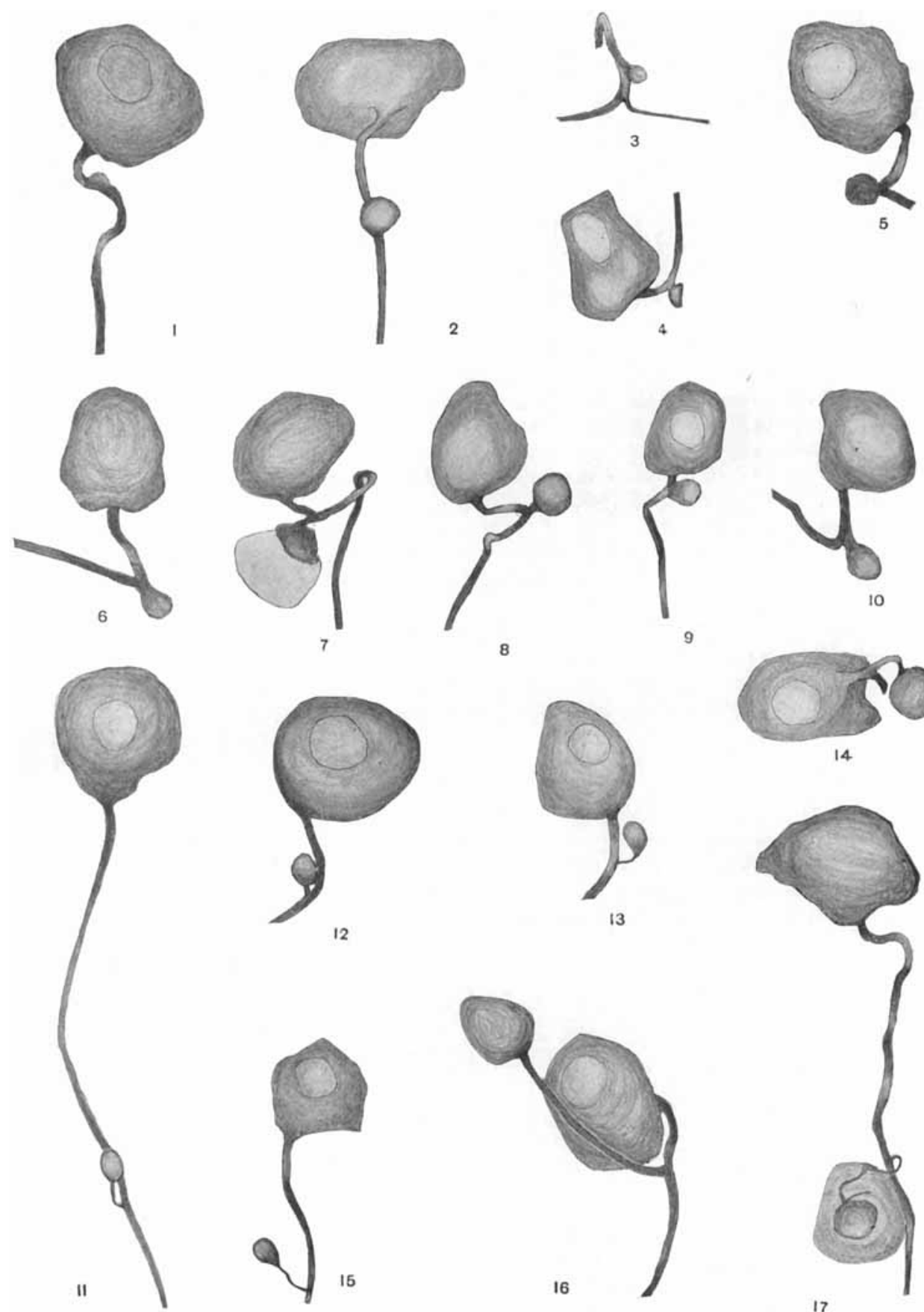

12
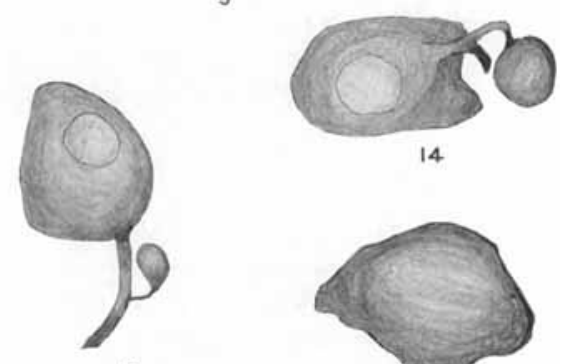

14

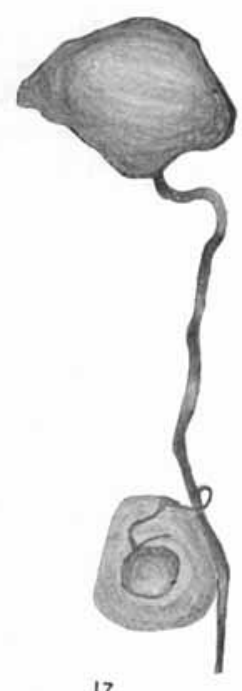




\section{PLATE 2}

\section{EXPLANATION OF FIGURES 18 TO 37}

Figs. 18 to 29 Show the anlage and metamorphosis of protoplasmic branches ending in end bulbs, which arise from the cell body of spinal ganglion cells and retain such relation in the adult stage. Figures 24,26 and 28 are from the spinal ganglia of rabbits six days old; the other figures of the series from spinal yanglia of rabbits one day old.

Figs. 18, 19 and 25 Show the anlage as protoplasmic buds, and the basal constrictions of such buds, of processes ending in end bulbs arising from the eell body of spinal ganglion cells.

Figs. 20, 21, 22, 23, 24 and 26 Present progressive stages in the metamorphosis of protoplasmic processes ending in end bulbs and arising from the cell body of spinal ganglion cells.

Figs. 27, 28 and 29 Present cells with short protoplasmic processes ending in relatively small variously shaped end dises with endo-capsular position.

Figs. 30 to 36 Present cells showing the anlage and metamorphosis of protoplasmic or collateral branches ending in end bulbs, which arise from the cell body at the base of the axon cone, which as the processes and axons undergo further development are drawn on to the axons, thus loosing their connection with the cell body.

Fig. 31 Taken from the spinal ganglion of a rabbit embryo one week before birth presents the anlage of such a process as the protoplasmic bud with basal constriction arising from the cell at the base of the axon-cone.

Figs. 30, 32 to 37 Show progressive developmental and metamorphic changes of such processes and show a wandering of their anlagen from the base of the axoncone to a position on the axon. 

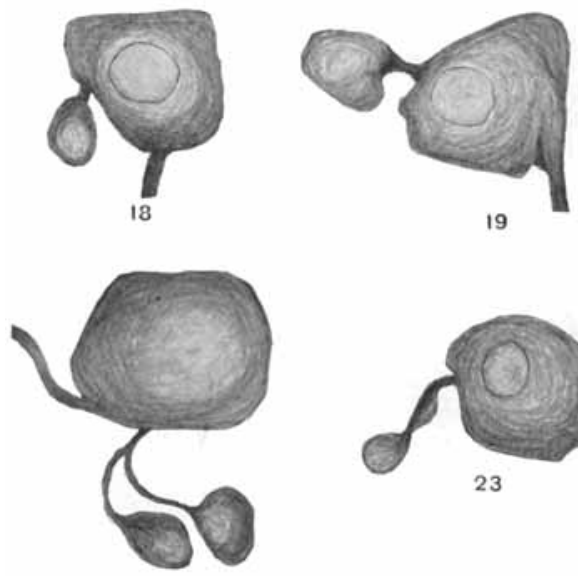

22

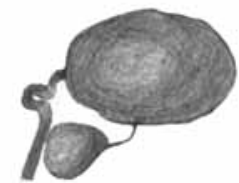

26
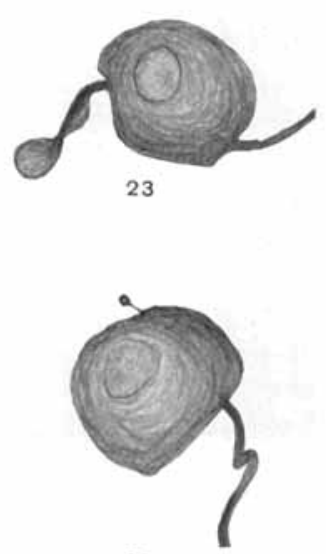

27

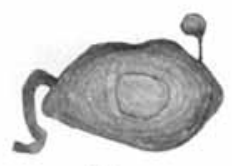

28

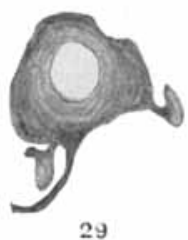

29
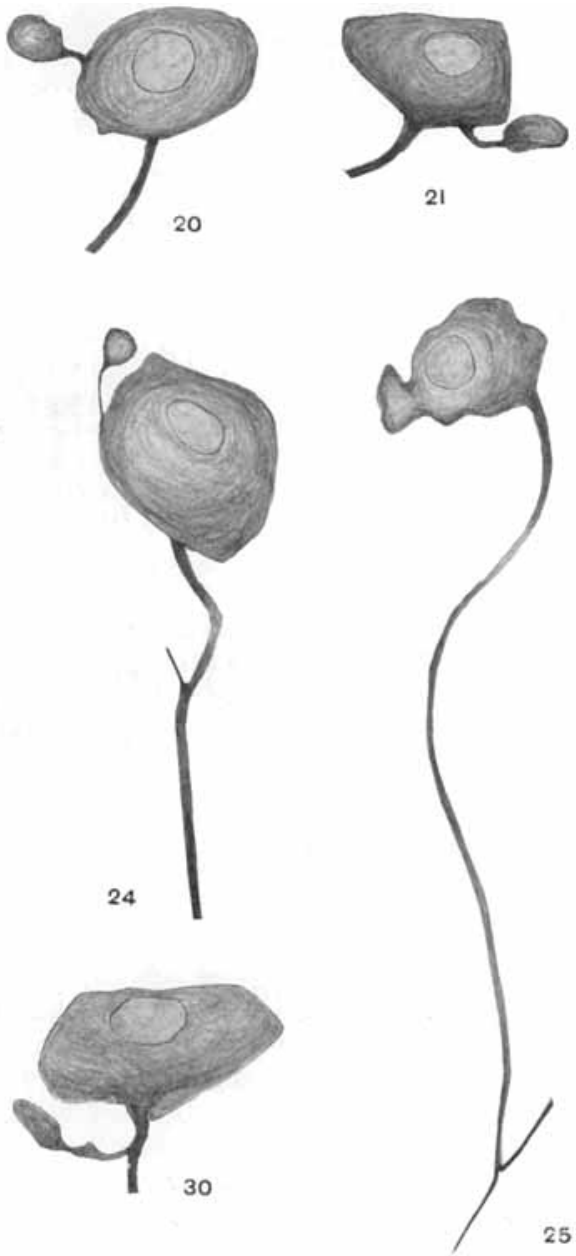

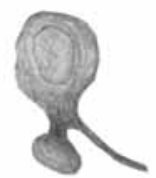

31

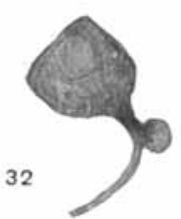

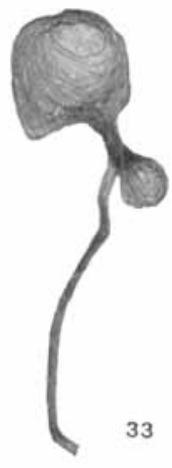
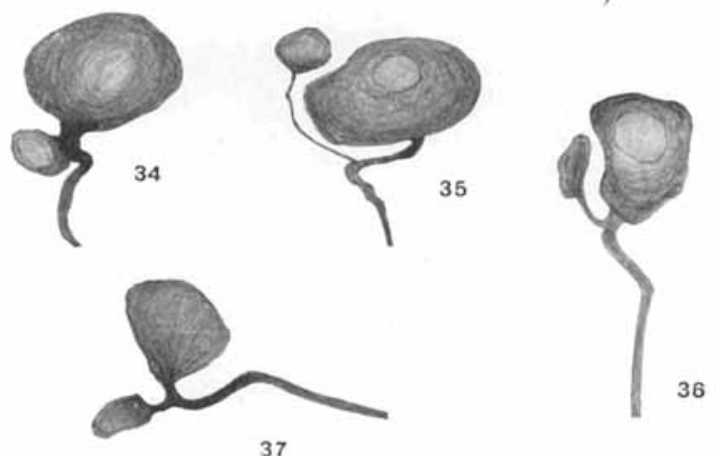


\section{PLATE 3}

\section{EXPLANATION OF FIGURES 38 TO 54}

Fras. 38 to 45 Present a series of cells showing the anlage and progressive metamorphosis of protoplasmic branches ending in end bulbs which arise from the base of the axon-cone and retain this relative position in later stages of development.

Fig. 38 From the spinal ganglion of a rabbit embryo one week before birth and shows the anlage as a bud of protoplasm with basal constrictions arising from the cell at the base of the axon-cone.

Figs. 39 to 45 From the spinal ganglia of rabbits one day old, show progressive stages in the metamorphosis of protoplasmic buds arising from the base of the axon-cone and developing into processes with end bulbs which retain this relative position.

FIg. 46 Spinal ganglion cell of a one-day rabbit. Primary axon with branched collateral, each branch ending in an end bulb.

Fig. 47 Spinal ganglion cell of a one day rabbit. Protoplasmic branch which arises from the cell body and collateral branch arising from the primary axon, each ending in an end bulb.

Fig. 48 Spinal ganglion cell, one day rabbit. Well developed protoplasmic branch ending in conspicuous end bulb, similar branch in anlage and collateral branch which arises from primary axon.

Fig. 50 Spinal ganglion cell, rabbit one day old. Primary axon from which arise three collateral branches with end bulbs one of which is lobulated.

Figs. 51, 52, 53 Spinal ganglion cells, one-day rabbit. Present each a primary axon from which arise two collateral branches ending in an end bulb; progressive stages in the metamorphosis of such.

Fig. 54 Spinal ganglion cell, one-day rabbit. This shows fenestration of protoplasm at the base of the axon cone. 
NEURONES OF PERIPHERAL SENSORY GANGLIA

G. CARL HUBER AND STACY R. GUILD

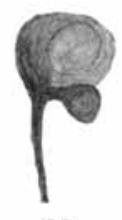

38

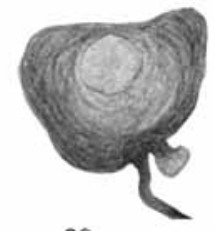

39

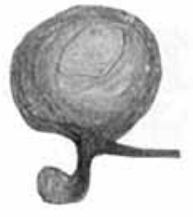

40

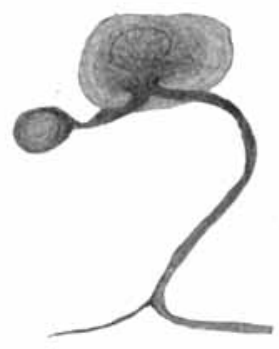

43

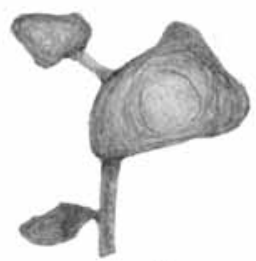

47

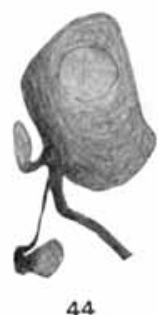

44

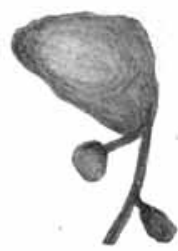

48
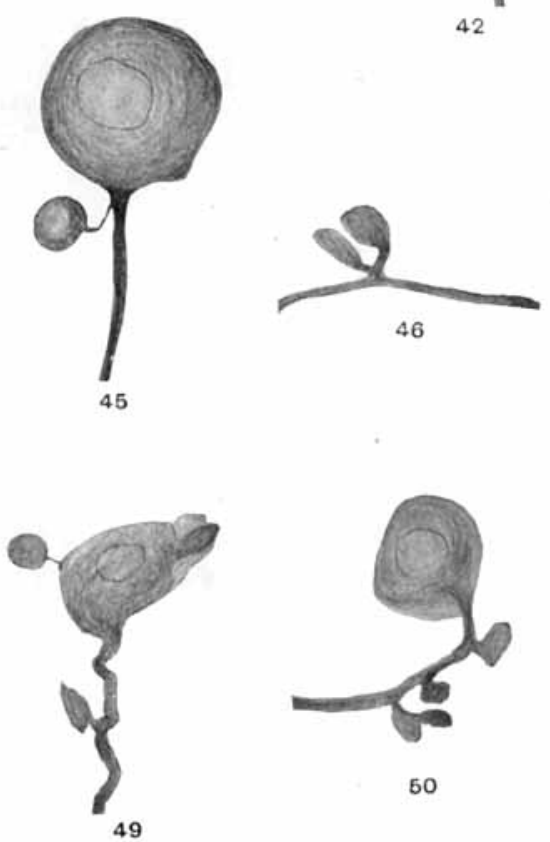
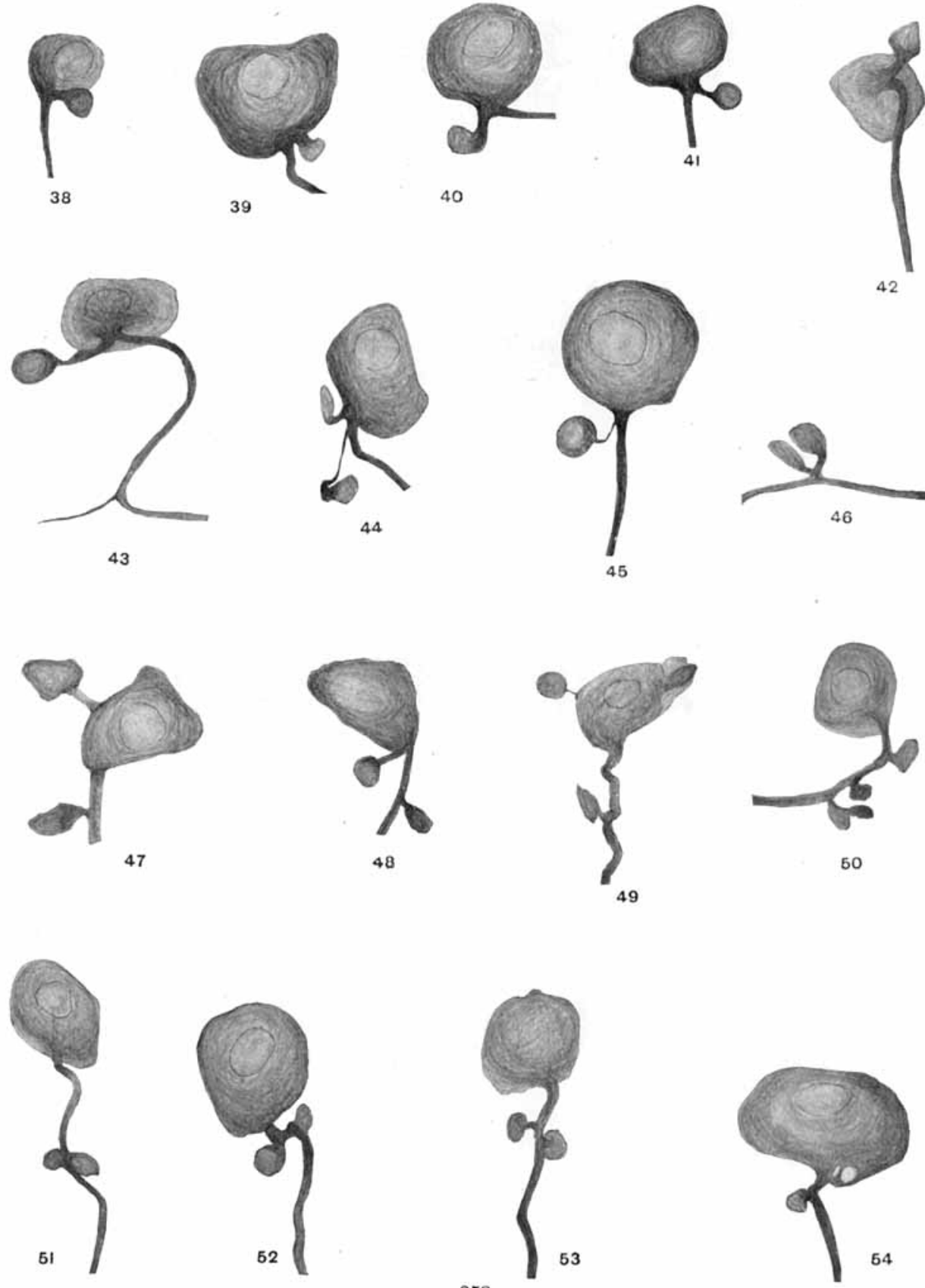